\title{
DOES SPIRIT OF NATIONALISM STILL EXIST THROUGH GUIDANCE $\&$ COUNSELING SERVICE ? \\ (The Fieldtrip Study Analysis at (SIKL) Indonesian School Students of Kuala Lumpur)
}

\author{
Siti Liana Nurun Nisa' \\ IAIN Kudus, Jawa Tengah, Indonesia \\ liananurunnisa06@gmail.com \\ Khilman Rofi` Azmi \\ IAIN Kudus, Jawa Tengah, Indonesia \\ rofiazmi@iainkudus.ac.id
}

\begin{abstract}
Abstrak
Penelitian ini bertujuan untuk mendeskripsikan tentang Roh Nasionalisme dalam layanan bimbingan da konseling (Studi analisis di (SIKL) Sekolah Indonesia Kuala Lumpur). Penelitian ini mengunakan Metode studi kunjungan lapangan. Dimana kunjungan belajar lapangan dilakukan secara online melalui zoom. Pendekatan yang digunakan adalah kualitatif. Pendekatan ini bersifat deskriptif berdasarkan pengamatan berupa kata-kata atau perilaku yang diamati. Sumber datanya beragam, seperti catatan observasi, sejarah, dan catatan wawancara. Sedangkan artikel ini sumber datanya dari hasil wawancara. Data penelitian yang terkumpul kemudian dianalisis dengan menggunakan pendekatan alaisis deskriptif. Hasil penelitian menunjukkan bahwa Guru BK memiliki peranan penting dalam membantu suksesnya pendidikan karakter. Di Malaysia, terdapat banyak orang Indonesia yang tinggal di sana. Maka, dihadirkan Sekolah Indonesia Kuala Lumpur sebagai sebuah upaya bangsa Indonesia menanamkan kepada setiap warga negaranya dimanapun untuk dapat merasakan pendidikan yang terintegrasi, yaitu sistem pendidikan nasional. SIKL merupakan sekolah Indonesia luar negeri yang memiliki komitmen untuk mencerdaskan siswa dan
\end{abstract}


mempromosikan budaya Indonesia di masyarakat global. Terdapat beberapa bentuk kegiatan yang mendukung karakter nasionalisme yakni dengan mengadakan eksrakulikuler kesenian, expression stage, pramuka, dan diplomasi budaya. Dari kegiatan tersebut siswa SIKL menjadi siswa yang berkarakter nasionalis kuat serta menjadi agen promotor budaya bangsa Indonesia di Malaysia.

Kata kunci: Bimbingan dan Konseling; Cinta Tanah Air; Siswa Sekolah Indonesia Kuala Lumpur

\begin{abstract}
Does Spirit of Nationalism Still Exist Through Guidance \& Counseling Service? (The Fieldtrip Study Analysis at (SIKL) Indonesian School Students of Kuala Lumpur). This study aims to describe the spirit of nationalism in guidance and counseling services (analytical studies at the Indonesian School of Kuala Lumpur (SIKL). This research uses a field visit study method. Where field study visits are conducted online via zoom. The approach used is qualitative. This approach is descriptive based on observations in the form of words or observed behavior. The data sources are diverse, such as observation notes, history, and interview notes. While this article is the source of the data from interviews. The research data collected was then analyzed using a descriptive analysis approach. The results of the study indicate that BK teachers have an important role in helping the success of character education. In Malaysia, there are many Indonesians living there. So, the Kuala Lumpur Indonesian School is presented as an effort for the Indonesian people to instill in every citizen everywhere to be able to experience an integrated education, namely the national education system. SIKL is an overseas Indonesian school that is committed to educating students and promoting Indonesian culture in the global community. There are several forms of activities that support the character of nationalism, namely by holding extracurricular arts, expression stages, scouts, and cultural diplomacy. From these activities, SIKL students became students with strong nationalist characters and became agents of promoters of Indonesian culture in Malaysia.
\end{abstract}

Keywords: Guidance and Counseling; Spirit Nationalism; Kuala Lumpur Indonesian School Students 


\section{A. Introduction}

Living abroad does not mean not having a high nationalism However, living abroad does have its own challenges. No longer faced with ethnic or regional differences. However, being faced with a foreign culture is also required to be able to mingle together. Who is he who is capable, will be able to survive and develop. Conversely, those who do not have the skills will be eroded by foreign cultures. The skill in question is the strength of character, where a person has character in defending religion, virtue, tolerance, responsibility and fairness, which are the characteristics of the Indonesian personality (Azmi, 2019).

The Indonesian nation is a nation within the frame of diversity which means it consists of various ethnicities, races, ethnicities and religions. Therefore, nationalism needs to be developed in every Indonesian citizen. Nationalism can be a motivation to participate in contributing to building a country with full dedication. So that the nationalism can maintain the integrity of the Indonesian nation. However, nowadays the spirit of nationalism is starting to fade. This is in line with Ismiyati's opinion, which states that the spirit of nationalism in the Indonesian nation is experiencing degradation. Most Indonesian citizens do not realize the importance of having a spirit of nationalism. (Ismayani, 2016: 146-147)

This is confirmed by research from Dr. Dadang Supardan from the Indonesian University of Education. The occurrence of conflicts between ethnicities, between religions and other disintegration phenomena is a condition of the Indonesian nation which is experiencing the degradation of spirit of nationalism. The nation's disintegration conflict has existed since 1997, this condition may be explained by the chaos theory that became known in science circles at the end of the 20th century. Simply put, the phenomenon of chaos can be described by the famous expression, "Does the flap of a butterly's wings in Brazil set. off a tornado in Texas ". Or some say "The flapping of a butterfly's wings in Sydney Harbor is enough to cause a hurricane two weeks later in Jamaica" $3 / 4$ starting from small and trivial problems can cause big chaos. (Dadang Supardan, 2013: 38)

The crisis of spirit nationalism is especially rife in the younger generation. The existence of acts of radicalism and intolerance indicates that the national identity is being threatened because of the arrogance of a group of people who carry the name of religion. Coupled with the displacement of Indonesian culture which presents a new pattern of westernization due to the impact of globalization (Azmi, 2018). (Harls Evan Siahan.) According to Ferry Kurniawan, the real form of the spirit nationalism for the country is that during the flag ceremony and singing 
the Indonesia Raya song, the ceremony participants do not seem to be devoted to following. They are more cool talking to their friends beside them. Second, there are many conflicts among students, resulting in violence with their own friends, which means it can threaten unity. (Farry, 2018: 115)

The decline in the quality of morals in life, especially among students, means that school assignments are to provide character education so that students can have characters that are in accordance with the values of goodness in life. This character education is aimed at emphasizing the value of spirit of nationalism, being honest, fair, caring and responsible. These values can become provisions for individuals to develop their potential and achieve their own success. From the results of social psychology research shows that successful people in the world are determined by the role of science by $18 \%$, the remaining $82 \%$ are determined by emotional skills, character, and the like. (Evinna, 2016: 26-27)

Education in Indonesia must be integrated starting from elementary school to high school and university levels. With character education based on spirit of nationalism, it is hoped that it can become a solution for the improvement of the Indonesian nation in the context of an advanced Indonesia by having quality human resources and having a strong spirit of nationalism. (Joned: 2013)

The things above really need to be applied to students, especially students who are currently studying abroad. Where now there are many radicalism ideas emerging in Indonesia and initially from abroad, which was planned by a few people with the intention of undermining the Republic of Indonesia. Students who received education abroad are easy targets for anyone who wants to destroy Indonesia to enter into radical ideologies. Another thing that might happen is the fading of the spirit of nationalism, because living abroad, which might feel more comfortable than in Indonesia. Thus, it will reduce the gold potential of Indonesia's young generation.

Indonesian Overseas Schools have been presented for the educational needs of Indonesian citizens who are living abroad. The goal is that they can continue to carry out education like the system applied in Indonesia. Now, 14 Indonesian schools have been established in various countries, one of which is the Kuala Lumpur Indonesian School (SIKL). SIKL is the oldest and largest Indonesian Overseas School in the world. Apart from being seen from the quantity of students which is more than other public schools, this SIKL also has good quality and can even become a national asset in introducing Indonesian culture abroad. Therefore, this article will try to see how much spirit of nationalism of Indonesian students who are studying abroad, namely at the Kuala Lumpur Indonesian School (SIKL). 
Although there have been several visits and research there. One of them is research from UMY (Yogyakarta Muhammadiyah University) on the implementation of the 2013 curriculum to develop religious attitudes of SIKL students. However, the discussion about character education for the spirit of nationalism, in SIKL is an interesting and useful new thing to discuss more deeply.

\section{B. Method}

The method used in this research is a field trip study. Where field learning visits are held online via zoom. The approach used is qualitative. This approach is descriptive based on observations in the form of words or observed behavior. (Hendrikus, 2010: 186) The qualitative approach aims to build knowledge statements based on constructive perspectives, namely meanings that come from experiences during a field trip study to build theories or pattern of certain knowledge about the character education of spirit of nationalism in SIKL. In qualitative research, knowledge is built through the interpretation of various diverse perspectives from the input of all participants involved in the research, not only from the research alone. The data sources vary, such as observational notes, history, and interview notes. While this article the data source is from the interview results. The interview technique was used because it was considered the most useful for obtaining information from respondents. Through interviews, respondents are given the opportunity to explain their opinions and share their own experiences and observations. (Nina, 2014: 1116) The interviewees in this study were Mrs. Halimatus Sya'adah and Mr. Sulton Kamal. The data analysis used was descriptive analysis. From the results of the Sriwijaya University proceedings, it is said that the descriptive analytic method is a research method that describes, and summarizing conditions from various data, there data is gathered through interviews or observation in field (Etty, 2016: 243) which means that descriptive analysis is to analyze, describe, and summarize. Various conditions, situations from various data collected in the form of interviews or observations about the problem under study that occurred in the field. The form or form of land love character education in SIKL is an activity that is researched and will be narrated in this article.

Tabel 1. Data Collection Instruments, Types of Data, Subjects, Objectives, and Analysis Used by Researchers

\begin{tabular}{ccc}
\hline $\begin{array}{c}\text { Data Collection } \\
\text { Instruments and Data } \\
\text { Types }\end{array}$ & Subjects and Objectives & Analysis \\
\hline Interview guidelines & SIKL Students and Teachers & Qualitatie
\end{tabular}




\begin{tabular}{ll}
\hline & Descripton \\
And Qualitative & The goal is to determine the application of \\
& character education for the spirit of \\
& nationalism.
\end{tabular}

\section{Result And Discussion}

Kuala Lumpur Indonesian School (SIKL) is one of the oldest Indonesian overseas schools among other Indonesian overseas schools. SIKL was founded 51 years ago, to be precise on July 10,1969. This overseas educational institution is not only an institution that is teaching and learning activities only. However, it is more than that, which is service in nature which means that SIKL prioritizes character education for its students. This is in accordance with the vision carried by SIKL, namely as an educational institution that is cultured, virtuous, and accredited, and has international quality. The missions are 1) To make education stronger and more noble so that it can reflect the characteristics of the nation. 2) Making Indonesian cultural arts sustainable, developing and recognizable to the global community 3) Incorporating eight national education standards. 4) Developing a national curriculum with a global perspective by implementing international cooperation.

The manifestation of this vision and mission can be seen starting from the mandatory competencies that must be fulfilled by SIKL teachers, namely pedagogical competencies. Where teachers are required to be able to develop effective and efficient learning strategies. Examples are Digital RPP and Digital Media Teacher which are included in the flagship program of SIKL. This is coupled with personal, critical and professional competences. As a teacher who is digugu and imitated, the figure of a teacher is a living curiculume which means a living curriculum. The attitude displayed by the teacher must be in accordance with the applied curriculum, namely a curriculum that is oriented towards character education. In addition, the ability to socialize with the local community is also very necessary, considering that this can have an impact on the reputation of this private school to be accepted and supported by its existence. All of that, continue to be carried out professionally in accordance with the existing code of ethics.

Strategies in shaping the nationalist character of SIKL learners are inseparable from the role of Guidance and Counseling Teacher. The efforts given are: 
1) Student and Parent Orientation

MOS-NB (New Normal School Orientation Period) is an orientation service for students to make it easier for them to adapt to their new environment. In 2020, these activities will only be attended by high school class XI-XII. Meanwhile, kindergarten to class X high school followed it virtually because it is still a covid-19 pandemic. Nonetheless, it did not diminish the significance of MOS this year. Not only for students, school orientation is also provided for guardians of learners with the aim that parents can understand and can direct the child's learning process when school starts. At the same time, SIKL launched RPP Digital as its flagship program.

2) Blue Print/Leson Guidance

Blue Print / Leson Guidance is a learning design application for the next one week. This application is a guarantee of the quality of SIKL to parents of students. It is hoped that it can provide parents with an idea of what their children will learn during school and can help the main milestones that children have to achieve in each lesson. This is an information service in the field of education that is strived by BK teachers.

3) Culture Before Learning

Every morning, SIKL teachers warmly welcome students. The teacher is already in front of the school to greet and ask how the students are doing. This, can build an emotional relationship between the two, and can provide a stimulus to be more enthusiastic in learning. Before starting to learn, SIKL also applies good habits that can shape student character, namely by reading Pancasila. According to behavioristic theory, learning is a repeated response so that it can form the expected attitude.

Extracurricular is a service for distributing BK teachers to students to develop their talents. There are 2 extracurricular activities at SIKL, namely compulsory and optional. As in Indonesia, the obligatory extracurricular activity in SIKL is scouting, because scouting is the implementation of Pancasila which is shed in trisatya and dasadharma as the militant generation of the Indonesian nation. The extracurricular choices are dance, angklung music, rampak drum, gamelan, vocal sound art, and martial arts martial arts. These activities are carried out according to the needs of students at SIKL, namely as a promoter of Indonesian culture in international commodities. This activity with the theme of art and culture is not just a side activity for students. However, the school provides a wide 
space with the SIKL Presentation Stage program. The program is a skill show program intended for students in the arts and culture once a week. This is evidence of the seriousness of SIKL in forming students with national analytic characteristics.

\section{Discussion the Nationalism by Character Building Education}

Character education is a process of helping students form character, care and responsibility based on common values that are mutually agreed upon in the national movement. Another definition says that character education is a social assistance, so that everyone can experience freedom and growth in the real world with other people. "Without character, people get nothing but a failed life." This statement shows the meaning of achieving a child's success which is expected by every parent to have meaning not only in the form of material or achievement without being balanced with honesty, responsibility, courage, justice, patience and compassion and spirit of nationalism. (Suti, 2017: 8-10). According to Rokhani, the character building of each individual can be done psychologically and socioculturally. Psychologically includes several aspects, namely cognitive, affective and psychomotor. Meanwhile, socio-culture includes individual interactions in family, school and society. (Rokhani, 2020: 61) So, the target of character education is all aspects.

The results of data obtained from interviews at the Kuala Lumpur Indonesian School (SIKL), it can be seen that from an early age, children are provided with character education. Because character is an important thing that can characterize, character and, identity for students. SIKL has also implemented character values in various forms of activities, both learning and extracurricular activities. So that students can have good habits in their daily life.

Character education in SIKL aims to influence the character of students by shaping their character. The way to influence it is with an example from the teacher including how to deliver material, speak and behave. The effort to build character has a higher meaning because it is not just a transfer of knowledge. However, it is more to instill awareness and commitment to each individual to behave wisely in their life. National education has the function of developing abilities and shaping dignified national character and civilization in order to educate the nation's life, aiming to develop the potential of students to become human beings who believe and fear God Almighty, have noble character, are healthy, knowledgeable, capable, creative, independent, and become a democratic and responsible citizen (Law No. 2003 Article 3). 
Learning and extracurricular activities in schools must be based on character education (Azmi, 2015), 20. Starting from early childhood education levels to tertiary institutions need to be integrated. So that character education can be implemented in levels effectively according to the development of children at their age. Not only students, character education also applies to teachers and other educators. This was held with the aim of forming a nation that is strong, has noble character, tolerant, moral, competitive, patriotic, science and technology oriented, and dynamic. (Euis Puspitasari, 2014: 46-47).

Character education is an important thing to implement because it has several functions, namely, first to develop basic potential. Second, to strengthen the nation's pluralistic behavior. Third, to improve the nation's civilization that is competitive in global relations. In a broader view, it is hoped that character education can manifest as a way to form individual characters that are in accordance with the Pancasila philosophy, have a good conscience, and can develop potential. Socially, individuals can take a role in the family, school and community to show a picture of a nation that is responsible, independent, advanced and prosperous. While globally, it is hoped that individuals can become agents of promoters of the values and culture of the Indonesian nation and become filters for the influence of foreign nations.

The government has made character education efforts through the Character Education Strengthening Program (PKK). PKK is a national movement that directs ways of thinking, behaving and acting to become wise individuals. Likewise in SIKL, one of the positive values that need to be instilled in students in SIKL is the character of spirit of nationalism Given the fact that apart from this school, it is not in Indonesia itself but in another country. Because if the character education for the spirit of nationalism is not implemented, it is likely that the children will not recognize the Indonesian nation and all kinds of culture which can have an impact on the lack of patriotism towards students there (Nur, 2019: 106107).

Character education that really needs to be emphasized in the postglobalization is the spirit of nationalism, as is the opinion above. Where the wider community is faced with foreign cultures that still need guidance in defending the spirit of nationalism . It is realized by preserving the culture, sacrificing for the benefit of the nation, protecting and defending the life and death of the nation. Therefore, the spirit of nationalism means that it already exists in the individual. (Jannah, 2018: 131). Spirit of nationalism also includes the embodiment of the 3rd Pancasila sila, namely the Indonesian association which is a guide in the life of the family, school and society. (Ismawati, 2015: 883) So, spirit of nationalism is a 
feeling that arises from the heart of a citizen, to serve, protect, defend, protect his homeland from all threats and disturbances. Aspects that need to be understood in the spirit of nationalism are: 1) The attitude of defending the country for the homeland, formed by the sense of pride, sense of belonging, and loyalty that each individual has in the country where he lives. 2) The nature of tolerance of Indonesian citizens.

An attitude of tolerance makes individuals who understand each difference, an attitude of mutual help, and a sense of mutual respect and esteem among all mankind. 3) Obedience to norms and rules in daily life obedience to rules and norms must be balanced with the attitude of the individual himself. (Siwiyanti, 2016).

The real picture of spirit of nationalism is with children or students studying in the future full of enthusiasm, discipline, diligence, obedience to family and school rules. (Nur Afiani, 2019: 09). The urgent thing that can lead students to serve their country is the seriousness of learning, the child's obedience to parents and teachers. Thus students will be successful in their studies so that they get useful knowledge and in the end the hope to serve the nation can be realized with the provision of knowledge and virtue. If, someone wants to serve the country but does not have knowledge capital, it is unlikely that they will contribute because they do not understand how. Repairing yourself is still confused, let alone to improve the nation. From the expert opinion above, it can be concluded that studying with perseverance is a form of spirit of nationalism . This feeling is shown by a sense of pride, care, and giving high respect for culture, social, political, economic, and so on for the nation (Azmi, 2019).

Seeing the importance of loving the country, it is fitting to develop it for every citizen. Some positive things that can be developed in the community to foster a sense of spirit of nationalism, including: 1) Singing the national anthem at every official activity in the community 2) Waving the red and white flag at moments of national day 3) Celebrating national holidays with competitions and cultural arts performances 4) Using batik on national batik day and others. (Naswatin Aziziyyah, 2019: 28).

Being in a state of people also does not always make all the shortcomings, but on the contrary even makes it an advantage. For the learning system there also has a lot of varied learning media both in the classroom (Indoor) and outside the classroom (Outdor), because SIKL which has a vehicle of education in the open space that is useful to dig information widely both in the academic field and in the formation of children's character. In addition to excelling in the academic field, 
SIKL students also excel in non-academic fields, one of which is: martial arts, badminton, basketball, and other extra activities. Students at SIKL also often perform and participate in various events such as Champions ship, and several other olympics. So that in addition to high-achieving students, students also have good character.

Intelligence is indeed needed, but intelligence without character will not be meaningful. So that the purpose of character education itself is to understand students as well as to practice them in daily life. According to Dian Hutami, he said that "character education is not just about teaching what is right and what is wrong, but also trying to instill good habits so that they are able to behave and act based on the values that have become his personality. (Dian Hutami, 2020: 8) So good character education that involves between good feelings, knowledge, and behavior, and it has also been practiced in SIKL.

Having a spirit of nationalism is an obligation for all Indonesian people without exception, it has even been established as the goal of education in Indonesia. (Fauzah Lutfian, 2017: 31-32) There are several things that can be done to increase the spirit of nationalism , including being proud to be Indonesian, even though they do not live in Indonesia but SIKL students have an identity as Indonesian citizens. So that the character of spirit of nationalism there is really necessary. And preserving culture, SIKL students are also taught to preserve several kinds of Indonesian culture, one of which is that students are taught to make batik, sing regional songs, play regional musical instruments and so on.

From this it can be concluded that the character of spirit of nationalism must be owned by all Indonesian people through an embodiment of the character and behavior of a person that reflects the spirit of nationalism they have. And the same is the case with SIKL, although not in Indonesia, the students do not lose their identity, cultural roots and traditions as Indonesian citizens, because in SIKL children are taught and introduced to Indonesian culture and arts such as playing gamelan instruments, regional dances and hasta works such as batik painting and so on.

Through various activities such as competitions or regional dance performances, regional songs, traditional costumes and so on, it is hoped to cultivate a sense of love for the homeland. So that it successfully makes citizens know the identity of the nation, and can respect each other, tolerance in cultural differences. (MF. Lestari Budi Utami, 2018: 463-464) As is the celebration of August 17, 1945, which is regularly performed by SIKL students on the eve of Indonesia's independence day. There is also a front group of the Indonesian 
Embassy in Kuala Lumpur which is a complete unit of alert, collector, enforcement, and guard. Gudep is a container for learners both from SIKL and outside SIKL based in Kuala Lumpur. The scout extracurricular activities are one of the efforts that can be used to cultivate the character of both learners, such as love for their own nation and country or commonly called spirit of nationalism. This is in accordance with the contents of Permendikbud No. 63 of 2014 (article 1), scouting education is the process of personality formation, life skills, and noble morals of scouts through the appreciation and experience of scouting values. (Astri Desy Fatmawati, 2018: 7)

SIKL is like a house with a solid foundation that has stuck in the hearts of its students, because apart from being a hearth for knowledge, it is also a character sharpening for children. Because indeed one of the functions of SIKL is as a representative of the Indonesian Embassy diplomacy which includes the culture in Indonesia. As explained above, it can be concluded that character education with the spirit of nationalism is indeed very closely related to one another, for example, students who are in SIKL even though they are in other countries, cannot be separated from their identity as Indonesian citizens.

\section{Discussion on the Role of the Kuala Lumpur Indonesian School (SIKL) in Implementing the Nationalism by Character Building Education}

The Kuala Lumpur Indonesian School (SIKL) has an important role in shaping the love of the motherland character for Indonesian students living in Malaysia. The general description implanted in SIKL is having a sense of pride, being willing to sacrifice, upholding the essence of national dignity, having a sense of protecting and protecting the sovereignty and honor of the Indonesian nation. Since its inception, SIKL has a commitment to mold its students into national characteristics. Because the presence of SIKL is a bridge for Indonesian students living in Malaysia, however, they are still receiving education like in Indonesia. The national character instilled in SIKL is intended to improve and enhance all behaviors that include customs, values, potentials, talents, abilities, and thoughts of the Indonesian people. (Sigit Dwi Laksana, 2015: 178). This commitment is also in line with the opening of the second paragraph of the 1945 Constitution, namely "And the struggle for the Indonesian independence movement has arrived at a happy moment to safely deliver the Indonesian people to the front gate of the independence of the Indonesian State, which is independent, united, sovereign, just and prosperous". With this, the founders of the State realized that by becoming an independent, united, sovereign, just and prosperous nation, the Indonesian nation would become dignified and respected by other nations. 
Violations or problems faced by students can be considered minimal, because students have a high sense of unity and really maintain the good name of their home country, namely Indonesia. Therefore, SIKL is a reflection of the spirit of nationality, namely by thinking, acting and having an insight that places the interests of the nation and the state above the interests of themselves and their groups. many (Aji, 2017: 13) The existence of this makes School Counselors do a lot of guidance services rather than counseling. So that School Counselors focus on student development. The focus of its development is in the form of curricular and extracurricular activities. In extracurricular activities, counseling teachers provide full space for students to develop their talents. The Expression Stage is a weekly show of talent, interest, and arts programmed by School Counselors From here, students explore a variety of Indonesian arts, ranging from music performances, dance, and traditional songs. SIKL is also a frequent performer on national and international events in Malaysia to present Indonesian arts. From the educational process, it is hoped that it can become a motor of movement to facilitate the development of character (Feriska Listrianti, 2019: 268).

Table 2. The Implementation Form of Spirit Nationalism Character Education at the Indonesian Kuala Lumpur School (SIKL)

\begin{tabular}{|c|c|c|c|}
\hline & Form of Activity & Activity Description & $\begin{array}{c}\text { The Value of Love Character } \\
\text { Education for the spirit } \\
\text { nationalism }\end{array}$ \\
\hline & Arts extracurricular & $\begin{array}{l}\text { Extracurricular arts include dance, } \\
\text { angklung music, rampak drum, } \\
\text { gamelan, vocal sound art, and } \\
\text { martial arts martial arts. }\end{array}$ & $\begin{array}{l}\text { A sense of pride in Indonesian } \\
\text { culture. }\end{array}$ \\
\hline & Scout & $\begin{array}{l}\text { Scouting is a mandatory } \\
\text { extracurricular related to the } \\
\text { application of Pancasila values. }\end{array}$ & $\begin{array}{l}\text { Discipline, independence, and } \\
\text { tolerance. }\end{array}$ \\
\hline & SIKL Expression Stage & $\begin{array}{l}\text { A one-week routine, talent, and arts } \\
\text { show program programmed by } \\
\text { Counselor }\end{array}$ & Be creative and confident. \\
\hline & Cultural Diplomacy & $\begin{array}{l}\text { SIKL actively participates in various } \\
\text { activities organized by Malaysian } \\
\text { schools. }\end{array}$ & Cooperation and unity. \\
\hline
\end{tabular}




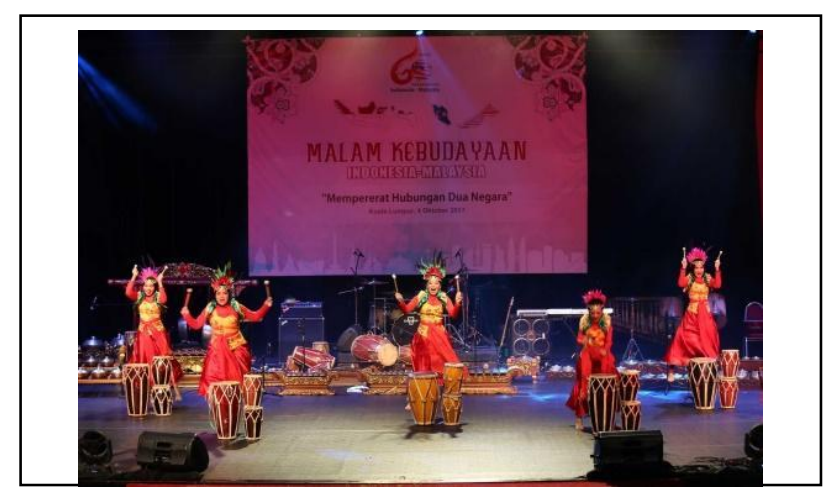

Pictures 1. SIKL Student Art Performance at the Indonesian-Malaysian Cultural Night Event organized by the Indonesian Embassy in Kuala Lumpur Malaysia.

\section{Simpulan}

From the results of the research and discussion above, it can be concluded that the presence of the Kuala Lumpur Indonesian School (SIKL) which implements the love character education for the country has been the answer to various problems that are now plaguing Indonesia, one of which is about radicalism and terrorism. This success is because SIKL consistently uses the national education system. So, the application is very applicable for students there. The role of SIKL is also increasingly evident in diplomatic relations between Malaysia and Indonesia. Materialized with the appreciation of the people and government of Malaysia for SIKL to be accepted as coexistence and mingling together and mutual tolerance. From the results of character education, SIKL is able to become a promoter of Indonesian culture and arts in the global community. 


\section{REFERENCE}

Aji, B. P., 2017. Implementasi Pendidikan Karakter Semangat Kebangsaan dan Cinta Tanah Air pada Sekolah Berlatar Belakang Islam di Kota Pasuruan. Jurnal Sains Psikologi, 6 (1), 13.

Astri, D. F., (2018). Pendidikan Karakter Cinta Tanah Air Melalui Kegiatan Ekstrakurikuler Pramuka Di Sdn Pilangsa (Skripsi, Universitas Muhammadiyah Surakarta).

Azmi, K. R. (2019). The Hoping Thinking Skill Model For Parents In Islamic Counseling Through Experiential Learning To Improve Children's Optimistic Attitude. Konseling Religi: Jurnal Bimbingan dan Konseling Islam. Vol. 10. No. 1. Juni 2019. Institut Agama Islam Negeri Kudus.

Azmi, K. R. (2019). Model Dakwah Milenial Untuk Homoseksual Melalui Teknik Kontinum Konseling Berbasis Al-Qur'an. Al-Balagh: Jurnal Dakwah dan Komunikasi. Vol. 4 No.1. Juli 2019. Institut Agama Islam Negeri Surakarta.

Azmi, K. R. (2018). Keterampilan Berpikir (Mind Skills) Pada Proses Konseling: Kajian Dalam Perkembangan Kognitif Neurosains. Konseling Edukasi: Journal of Guidance and Counseling. Vol 2.No.1. Juni 2018. Institut Agama Islam Negeri Kudus.

Azmi, K. R. (2015). Enam Kontinum Dalam Konseling Transgender sebagai Alternatif Solusi untuk Konseli LGBT. Jurnal Psikologi Pendidikan dan Konseling: Jurnal Kajian Psikologi Pendidikan Dan Bimbingan Konseling, 1 (1), 50. https://doi.org/10.26858/jpkk.v1i1.1136.

Dian, H. (2017). Semangat Kebangsaan Dan Cinta Tanah Air. Jogjakarta: Cosmic Media Nusantara.

Dadang, S. (2013). Tantangan Nasionalisme Indonesia Dalam Era Globlasasi. Jurnal Ilmu-Ilmu Sejarah, Budaya dan Sosial, 2 (4), 38

Evinna, C. H., Amold, C., 2016. Implementasi Pendidikan Karakter di Sekolah Melalui Keteladanan dan Pembiasaan. Jurnal Pendidikan Dasar Indonesia, 01 (02), 26-27.

Etty S,, Pandu, A., Dedi, R, R. (2016). Global Competitiviness:The Dynamics of Local, Regional, \& National Changes. Proceeding 2nd Sriwijaya Economics, Accounting, And Business Conference, Palembang : 23-24 November 2016. 
Hal. 243.

Euis, P. (2014). Pendekatan Pendidikan Karakter. Eduecos, 3 (2), 46-47.

Fauzah, L. (2017). Pembentukan Karakter Cinta Tanah Air Di Sekolah Dasar Negeri Argosari 01 Jabung Malang (Skripsi, UIN Maulana Malik Ibrahim Malang).

Ferry, K., Ruslan, Awaludin. (2018). Pelaksanaan Penanaman Nilai-Nilai Nasionalisme Pada Siswa SD Negeri Unggulan Sibreh. Jurnal Ilmiah Pendidikan Guru Sekolah Dasar, 3 (1), 115.

Feriska, L., 2019. Urgency Of Character Education In MAN 1 Probolinggo. Jurnal Pedagogik, 06 (01), 268.

Hendrikus, T. W. G. (2010). Pendekatam Kualitatif dan Kontribusinya dalam Penelitian Administrasi Publik. Jurnal Ilmu Administrasi, 7 (3), 186.

Jannah, R. W., Sri. (2018). Penerapan Nilai-nilai Cinta Tanah Air di Kalangan Mahasiswa. Jurnal Dinamika Governance FISIP UPN, 08 (02), 131.

Joned, B. W. L. (2013). Kebijakan Penanaman Nilai-Nilai Nasionalisme Pada Siswa di SMA Negeri 1 Ambarawa (Sekripsi, Universitas Negeri Semarang).

Ismawati, Y. T., Suyanto, T. (2015). Peran Guru PKN dalam Membentuk Sikap Cinta Tanah Air Siswa Di SMA Negeri 1 Mojosari Kabupaten Mojokerto. Jurnal Kajian Moral dan Kewarganegaraan. 02 (03), 883.

Ismayani. (2016). Hubungan Pemahaman Nilai-nilai Nasionalisme dengan Sikap Cinta Tanah Air Siswa Kelas V Sekolah Dasar. Jurnal Pendidikan Guru Sekolah Dasar, 12 (05), 146-147.

Lestari, B. U. (2018). Pendidikan Karakter Cinta Tanah Air dan Kebhinekaan Melaui Lomba Kebersihan dan Keindahan Kelas dengan Tema Adat Nusantara. Jurnal Pendidikan Riset \& Konseptual, 2 (4), 463-464.

Naswatin, A., 2019. Pembentukan Karakter Cinta Tanah Air untuk Menumbuhkan Sikap Nasionalisme Siswa Di MTSN 7 Malang. (Sekripsi, UIN Malang).

Nina, N. (2014). Teknik Sampling Snowball dalam Penelitian Lapangan. Jurnal Comtech, 5 (2), 1116.

Nur, T. A., Husni, W., Khusnul, F., (2019). Pelaksanaan Penguatan Pendidikan Karakter Membentuk Karakter Cinta Tanah Air. Jurnal Mimbar Ilmu, 24 (1), 106-107.

Nurafia, H. (2019). Upaya Penanaman Cinta Tanah Air (Skripsi, IAIN Purwokerto). 
Rokhani., Cicilia, T. C. (2020). Mewujudkan Peserta Didik Berkarakter Indonesia Melalui Peningkatan Penanaman Cinta Tanah Air : Best Practice Di Sd Negeri Dengkek 01 Pati. Journal Industrial Engineering \& Management Research (Jiemar), 1 (2), 61.

Sukiyat. (2020). Strategi Implementasi Pendididkan Karkter. Surabaya : Jakad Media Publishing.

Sigit, D. L., (2015). Urgensi Pendidikan Karakter Bangsa di Sekolah. Jurnal Muaddib, 05 (01), 178.

Siwiyanti, E. (2016). Efektivitas Implementasi Pendidikan Karakter Cinta Tanah Air Berbasis Layanan Bimbingan Klasikal dengan Pendekatan Experiential Learning (Skripsi, Universitas Sanata Dharma Yogyakarta).

Suti. (2017). Penanaman Karakter Cinta Tanah Air Melalui Kegiatan Ekstrakulikuler di MI Ma'arif NU Pageraji Cilongok Banyumas (Skripsi, IAIN Purwokerto). 